\title{
Sick of sitting
}

\author{
James A. Levine ${ }^{1}$
}

Received: 25 November 2014 / Accepted: 12 March 2015 /Published online: 24 May 2015

(C) Springer-Verlag Berlin Heidelberg 2015

\begin{abstract}
Sitting too much kills. Epidemiological, physiological and molecular data suggest that sedentary lifestyle can explain, in part, how modernity is associated with obesity, more than 30 chronic diseases and conditions and high healthcare costs. Excessive sitting-sitting disease-is not innate to the human condition. People were designed to be bipedal and, before the industrial revolution, people moved substantially more throughout the day than they do presently. It is encouraging that solutions exist to reverse sitting disease. Work environments, schools, communities and cities can be re-imagined and re-invented as walking spaces, and people thereby offered more active, happier, healthier and more productive lives.
\end{abstract}

Keywords Chronic disease - Diabetes · Non-exercise activity thermogenesis - Obesity Physical activity . Review

\section{Abbreviations \\ NEAT Non-exercise activity thermogenesis}

\section{In the beginning, we were bipedal}

There is debate regarding the evolutionary steps that resulted in bipedalism [1]; suffice it to say, the human evolved over hundreds of thousands of years to be upright, two-legged, walking beings [2-6]. Over time, people evolved to explore by foot, to manually invent tools and weapons and to think while upright and responding to environmental cues,

James A. Levine

levine.james@mayo.edu

1 Mayo Clinic, 13400 East Shea Blvd, Scottsdale, AZ 85259, USA perceived threats and calculated opportunities [7]. Thousands of years ago, living was dynamic. Compare chasing a bison over a cliff to choosing a meat package at the supermarket and contrast hand-chipping a flint for a spear versus engineering a cyber attack. Prior to the industrial revolution 200 years ago, $90 \%$ of the world's population lived in agricultural communities where shelter, nutrition and reproduction all required physical exertion. Data from agricultural communities suggest that, prior to the industrial revolution, people sat for $300 \mathrm{~min}$ per day and lived actively [8]. From 1760 onward, the industrial revolution precipitated urbanisation; it was the predominant demographic shift into modern history [9-11]. Now more than half the world's population live in cities and urbanisation continues to grow worldwide [12]. In industrialising countries, 1908 saw the introduction of factories that used conveyor belts, and in the 1940s, modern chair-based offices were developed. In both cases, the environments and furnishings were designed to promote productivity and limit movement by having people sit. Walking around factories or offices was perceived as wasted time. Fast-forward to the present day, and office workers can sit for up to $15 \mathrm{~h}$ in a single day! [13].

People are designed to work and socialise while on their legs and to sit in order to rest; the default position for people is to be up and moving. Is it a surprise that modern people who default to sitting (e.g. 'take a seat') experience negative physical, medical and psychological consequences? Do modern environments, however, give us any other choice except to sit?

\section{Modern environments foster sitting}

Environments foster sedentariness in many ways and at multiple societal levels. On an individual level, a person is confronted with environmental cues to sit throughout the day, e.g. drive-through banks [14]. Modern homes contain many tools of convenience, each one decreasing non- 
exercise activity thermogenesis (NEAT) [15]. Workplaces [16, 17] and schools [18-20] are major environmental drivers of NEAT. Communities encourage inhabitants to be sedentary. For instance, when data for 3,139 US counties were reviewed, encompassing the majority of the US population, sedentariness correlated with poverty, as did obesity and diabetes [21]. No personal choices, behaviour or genetics can explain this association because people do not choose to live in poverty. Other factors that may explain why people living in poverty-dense areas are likely to be sedentary include crime, poor housing conditions, poor health and lack of access to activity-promoting opportunities.

\section{Cityscapes and sitting}

More than half the world's population live in cities, with the fastest growth occurring in some of the world's poorest countries [22]. Active leg-based transportation is common in a number of European cities, including Copenhagen and Amsterdam. Rain or shine, Amsterdam is swamped with bicycles [23]. In the USA, there is variability in how cityscapes encourage or inhibit walking. New York City, San Francisco, Boston, Philadelphia and Miami are among the most walkable $[24,25]$, suggesting that weather is not a key determinant. Los Angeles, on the other hand, exemplifies a city that inhibits walking because of poor air quality and a roadway design that imposes the use of motor transport [26, 27]. Los Angeles has the most congested streets in the USA. The average Los Angeles driver experiences $72 \mathrm{~h}$ of traffic delays per year. Overall, US drivers waste 3 billion gallons of gas per year and 6 billion hours sitting in traffic [28]. Cityscapes that promote sedentariness are unhealthy in other ways, too.

Public policy [29] and prevailing social ambience can impact sitting [30-32]. In many societies, gender- and agedefined roles impact sedentariness [32-34]. Stereotypes about obesity can perpetuate low NEAT, promote bullying in children and permit discrimination [35-38]. Religion, too, can factor into promoting sedentariness [39].

Overall, the environment influences sitting in multiple ways. The precise magnitude of environmental influences on NEAT and/or sitting is poorly quantified because it is difficult to conduct societal-wide sedentariness research, gather valid population data and account appropriately for the vast array of variables as wide-ranging as religion, sociology, wealth and weather.

\section{The impact of sitting on the human body. The physiology of sitting too much}

Studies illustrate the physiological implications of sedentariness. Sixteen lean, healthy volunteers were overfed
$1,000 \mathrm{kcal} /$ day $(4.18 \mathrm{MJ} /$ day) above their weight maintenance needs for 2 months. Those volunteers who increased their NEAT the most gained the least amount of body fat. Some volunteers increased their NEAT by $>700 \mathrm{kcal} /$ day ( $>2.93 \mathrm{MJ} /$ day) [40, 41]. Conversely, those people who did not increase their NEAT-those who stayed seated-were the most prone to gain body fat.

Underwear interlaced with sensors that captured body postures and movement was used to examine how a person can increase their NEAT by $>700 \mathrm{kcal} /$ day $(>2.93 \mathrm{MJ} /$ day $)$. People who increase habitual walking (not purposeful exercise) can 'burn-off' the excesses of consumption. Conversely, people who overeat and stay seated gain the most body fat [41].

Human energetics can explain how NEAT can vary so greatly depending on how a person lives. Basal energy expenditure is the energy a person expends at complete rest. It increases with greater body size [42]. A seated person working at a computer screen generally expends $5 \%$ above basal energy expenditure-10-20 kcal/h $(0.04-0.08 \mathrm{MJ} / \mathrm{h})$ [42]. Within minutes of standing and walking, a person's energy expenditure doubles. An average person moving at $1-2 \mathrm{mph}(1.6-3.2 \mathrm{kph})$ expends $100-250 \mathrm{kcal} / \mathrm{h}$ $(0.42-1 \mathrm{MJ} / \mathrm{h})$ above basal energy expenditure [42]. The standard workday of three hypothetical office workers are compared in Fig. 1. The figure illustrates that, during work hours alone, one worker can expend $1,000 \mathrm{kcal} /$ day $(4.2 \mathrm{MJ} /$ day $)$ more than another worker, even when both people have similar desk-based jobs. This accounting does not even consider the energy expenditure of leisure, which also varies greatly from sedentary screen time (100 kcal/evening) $(0.42 \mathrm{MJ} /$ evening) to active leisure (500-1,000 kcal/evening) (2.1-4.2 MJ/evening). It is not surprising, therefore, that when a group of people with similar desk-based jobs is studied, those who sit more have greater body fat than those who walk more [43, 44]. Interestingly, people who are most active in their leisure time are also most active at work [43]. Overall, people with obesity tend to sit for $2.5 \mathrm{~h}$ per day more than lean people with similar professions, economic statuses and home environments [44]. People with obesity tend to sit; walkers tend to be leaner.

There are other physiological factors that influence NEAT, including age, weather, concomitant illness, medications and sleep [45-48]. Sleep deprivation, for example, is associated with obesity [49-51] because, when people are deprived of sleep, their cumulative daily NEAT does not increase, despite their being awake for longer. Energy intake, however, does increase [52]. In sleep deprivation, positive energy balance and weight gain occur through the disassociation of energy intake from NEAT. It is interesting that a key neurochemical involved in wakefulness, orexin, is also a direct mediator of NEAT [53-55] and is integrated into the feeding circuits [56]. 
Fig. 1 Hypothetical workplace energy expenditures for (a) The chair-locked worker who sits most of the day; (b) the NEATthusiast who converts half of their six, 0.5-h meetings to walking meetings, parks a little farther away from the office, and takes 10 min 'active breaks' during the work day and a brief stroll at lunch time; and (c) the NEATthlete who conducts all work meetings while walking, has a chair-less desk, takes a $0.5 \mathrm{~h}$ walk at lunchtime and cycles to work

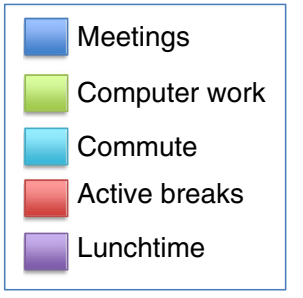

a Chairlocked

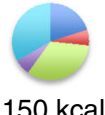

\section{b NEATthusiast}

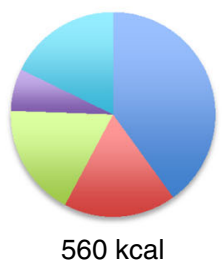

C NEATthlete

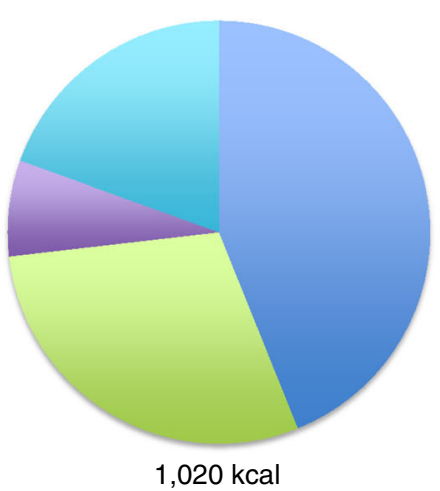

\section{The molecular biology of sitting too much}

Minor, short bursts of NEAT break up sitting and activate multiple molecular mechanisms. For example, in muscle, NEAT bursts improve insulin handling [57] via mitochondrial factors, lipolysis and insulin-receptor action [58-62]. The aforementioned associations between sitting, adiposity, insulin sensitivity and metabolic dysfunction can explain the association between excess sitting and cancer, in part [63-65]. Excess sitting also disrupts sex hormone function, insulin-like growth factors, inflammation and vitamin handling [66]. Prolonged sitting adversely impacts bone growth factors [67, 68] and, coupled with decreased weight bearing, sitting is associated with lower bone mineral density and osteoporosis $[69,70]$. Being seated alters the activation patterns of multiple weight-bearing muscles and, therefore, excessive desk use is associated with adverse back curvature, back pain [71-74] and upper extremity problems such as carpel tunnel syndrome $[75,76]$. Movement is neurologically linked to brain centres outside the motor control centres [53, 77-85]. Perhaps this assembly can explain the relationship between sedentariness, low mood, depression and dulled intellectual function [86, 87]. Furthermore, a person's predisposition to sitting is partially predicated by genetic factors, although how these factors interface with environmental cues is not understood [14, 88-90].

En masse, the physiological evidence suggests that high levels of NEAT occur in the lean population, whereas low NEAT/sedentariness is linked to obesity. Sitting is ultimately a behaviour with environmental, sociological and biological cues. The organisational hub is in the brain.

\section{The chair-locked brain}

When people overeat, NEAT increases. This suggests that circuits exist to integrate food intake and NEAT [91]. For

example, if a person rakes leaves all day, they become hungry. It is unlikely that the integration of NEAT and food intake is limited to humans, because when wolves, horses and dogs run a lot, they eat a lot, too [92].

While overeating increases NEAT, starvation decreases NEAT. Keys and colleagues showed that prisoners decreased their spontaneous movements when starved [93, 94]. The link between starvation and NEAT occurs across species and genera $[95,96]$. All species that have been studied show similar responses to starvation: first, there is a short-term increase in NEAT (ascribed to foraging), but once starvation is prolonged, NEAT decreases-even in fish [97]. Excess food and undernutrition evoke heightened and lowered NEAT, respectively, implying that a central connection exists between these two variables.

NEAT and energy intake connect in the hypothalamus. Several neuromodulators influence the paraventricular nucleus of the hypothalamus to regulate NEAT, such as orexin A and neuromedin $U$ [54, 56, 80, 98, 99]. Orexin A is especially interesting, as it is an arousal protein associated with wakefulness - the period of the day when people move. When orexin A is injected into the paraventricular nucleus of the hypothalamus, NEAT increases in a dose-dependent fashion. The central effect of orexin $\mathrm{A}$ is blunted in rats inbred for obesity $[53,80]$. Furthermore, orexin A is directly integrated with neuromodulators of appetite [100], muscle efficiency [53] and adipokines [100, 101]. The complete circuit for these interactions has not been fully mapped. However, these effects, and others like it, could explain why some people with a tendency to develop obesity are predisposed to sitting and eating in excess of energy needs. Conversely, people with heightened responsiveness to NEAT signals move more, have higher NEAT, maintain less body fat and resist obesity.

NEAT is influenced by other sensory inputs. For instance, how does a person who rakes leaves for several hours know that they are tired and sense the need to take a sitting break? What is the hierarchical interplay between behaviour and 
neurochemistry whereby a person decides to conduct a professional meeting while walking instead of sitting? In both of these examples, there are likely to be multiple sensory inputs from the musculature, joints, tendons, nerves, metabolic systems and multiple brain regions. The response systems are likely to be hierarchical and complex, whereby NEAT activation is concomitantly affected by behaviour, environment and social cues. Bench-based biology bolsters the evidence that NEAT is regulated principally in the hypothalamus. However, field-based observations suggest that the integration of NEAT with life is complex and functions across the domains of biology, behaviour, environment and sociology; therefore, across many neuroanatomic domains as well.

NEAT changes in response to sudden environmental stimuli, e.g. jumping out of the way of a bus, and with short- and long-term illness, e.g. influenza and congestive heart failure [102]. NEAT also changes over the long term, e.g. with changes in food availability and with the seasons. NEAT changes across a person's lifespan - compare the frenetic energy of a young child $[103,104]$ to the deliberate gait of an elderly person $[45,105]$. The age-decline in NEAT has been linked to changes in telomere length [90]. Historically, most people in agricultural communities moved throughout their day, and now most people sit for most of their day, so it is self-evident that movers can become sitters. If complex neurological systems regulate NEAT, what is the mechanism for NEAT adaptation? The central nervous system-both anatomically and biochemically - contains adaptive mechanisms that enable the brain to change its structure and function. Some of these neuroplasticity factors have been linked to NEAT and, by inference, to sitting $[84,106]$. Several human experiments suggest that sitters can become movers [107, 108], and so it is plausible that central neuroplasticity factors influence human NEAT. Perhaps because the brain adapts more rapidly in the young, adaptation to NEAT-promoting environments occurs more readily in the young than in the elderly. Which epigenetic factors are important in NEAT adaptation remain unknown [106].

Excessive sitting occurs in most people in modern society because of sociological, behavioural and biological cues. Excessive sitting is a concern because it is harmful. The illnesses associated with sedentariness are discussed next.

\section{Sitting sickness}

Sedentariness and low NEAT may be important factors in obesity [109], but it is less obvious as to why sedentariness is causally associated with diabetes and 33 other chronic diseases and conditions [90]. To illustrate the impact of sitting, in one experiment, healthy volunteers were provided with three meals and encouraged to remain sedentary thereafter. The same participants, on another occasion, were provided with similar meals and asked after they had eaten to walk for $15 \mathrm{~min}$ at $1.5 \mathrm{mph}(2.4 \mathrm{kph})$ [110]. Continuous glucose monitoring showed that the short walks halved postprandial glycaemic excursion, regardless of when the meal was consumed. In this instance, and in several other experiments [111, 112], the data underscore how prolonged sitting increases insulin resistance and that breaking up sitting time can improve glucose handling [111-113]. These data provide a physiological rationale as to why sitting is associated with type 2 diabetes and gestational diabetes [114-116].

Thirty-five chronic diseases and conditions are associated with sedentariness [90], including frailty in the elderly [117-120], weight regain after therapeutic weight loss [121, 122], hypertension [123], osteoporosis [69, 124-126], malignancies such as breast [23] and prostate [127] cancer, cardiovascular disease [102, 128], male erectile dysfunction [129], depression [130], and back and musculoskeletal pain [75, 131]. Improved physical activity also helps with addictions to alcohol, opiates and cigarettes [132-135]. Chronic diseases and conditions associated with sedentary behaviour [90] impact approximately $70 \%$ of patients [136] and the majority of US healthcare costs [137], and so the fiscal consequences of a sedentary lifestyle are enormous.

\section{Conclusion}

Excessive sitting is a common pathway that contributes to numerous chronic diseases such as obesity, type 2 diabetes, cardiovascular disease and multiple types of cancer. Physiological and molecular mechanisms can explain these associations. The good news is that people can adapt; if work places, schools and cityscapes could be designed to promote activity, the new default posture could be up and moving. Upwardly mobile people could become healthier.

Sitting science and solutions to sedentariness are in their infancy. Scientific enquiry is important to understand the causality and consequence of sitting and to validate approaches to reverse sedentariness. But if the curse of lethal sitting is to be reversed, a societal-wide approach is needed.

Sedentariness is a transdisciplinary problem that hurts many people and therefore requires a transdisciplinary response. Entrepreneurs, policy makers, health professionals, teachers, industrialists, lawyers, business leaders, scientists, healthcare providers and other key leaders will need to get up, leave the comfort of their specialties, and achieve change in coalition. Individuals too must stand united. Ultimately, individuals are consumers, control school and company boards, work, attend educational centres, buy stock and decide elections. The challenge of sedentariness is as societal as it is personal: Homo sedentarius, arise. 
Duality of interest The author declares that there is no duality of interest associated with this manuscript. However, JAL declares that he consults to Kersh Health Inc., Gruve Inc, SP Health Inc. and Gentag Inc. He does not receive fees from these organisations but has the potential to earn royalties. The author consults, without fee, to Apple Computer.

Contribution statement The author was the sole contributor to this paper.

\section{References}

1. Morgan E (1993) Bipedalism. Nutr Health 9:193-203

2. Pontzer H, Rolian C, Rightmire GP et al (2010) Locomotor anatomy and biomechanics of the Dmanisi hominins. J Hum Evol 58: 492-504

3. Barker G, Barton H, Bird M et al (2007) The 'human revolution' in lowland tropical Southeast Asia: the antiquity and behavior of anatomically modern humans at Niah Cave (Sarawak, Borneo). J Hum Evol 52:243-261

4. Bennett MR, Harris JW, Richmond BG et al (2009) Early hominin foot morphology based on 1.5-million-year-old footprints from Ileret, Kenya. Science (New York, NY) 323:1197-1201

5. Richards MP, Pettitt PB, Trinkaus E, Smith FH, Paunovic M, Karavanic I (2000) Neanderthal diet at Vindija and Neanderthal predation: the evidence from stable isotopes. Proc Natl Acad Sci U S A 97:7663-7666

6. Carroll RL (1997) Patterns and processes of vertebrate evolution. Cambridge University Press, Cambridge

7. Heitmann BL, Westerterp KR, Loos RJ et al (2012) Obesity: lessons from evolution and the environment. Obes Rev 10:910-922

8. Levine JA, McCrady SK, Boyne S, Smith J, Cargill K, Forrester T (2011) Non-exercise physical activity in agricultural and urban people. Urban Stud 48:2417-2427

9. Hibbs DA Jr, Olsson O (2004) Geography, biogeography, and why some countries are rich and others are poor. Proc Natl Acad Sci U S A 101:3715-3720

10. Perdue WC, Stone LA, Gostin LO (2003) The built environment and its relationship to the public's health: the legal framework. Am J Public Health 93:1390-1394

11. Doyle R (2006) Not so revolutionary. Recent advances are no third industrial revolution. Sci Am 295:42

12. Capon AG (2007) The way we live in our cities. Med J Aust 187: 658-661

13. Matthews CE, Chen KY, Freedson PS et al (2008) Amount of time spent in sedentary behaviors in the United States, 2003-2004. Am J Epidemiol 167:875-881

14. Robinson S, Yardy K, Carter V (2012) A narrative literature review of the development of obesity in infancy and childhood. J Child Health Care 16:339-354

15. Lanningham-Foster L, Nysse LJ, Levine JA (2003) Labor saved, calories lost: the energetic impact of domestic labor-saving devices. Obes Res 11:1178-1181

16. Smith MJ, Conway FT, Karsh BT (1999) Occupational stress in human computer interaction. Ind Health 37:157-173

17. Thomas L, Williams M (2006) Promoting physical activity in the workplace: using pedometers to increase daily activity levels. Health Promot J Austr 17:97-102

18. Fernandes M, Sturm R (2010) Facility provision in elementary schools: correlates with physical education, recess, and obesity. Prev Med 50(Suppl 1):S30-S35

19. Fernandes MM, Sturm R (2011) The role of school physical activity programs in child body mass trajectory. J Phys Act Health 8: 174-181
20. Mendoza JA, Levinger DD, Johnston BD (2009) Pilot evaluation of a walking school bus program in a low-income, urban community. BMC Public Health 9:122

21. Levine JA (2011) Poverty and obesity in the U.S. Diabetes 60 : 2667-2668

22. UN-Habitat (2005) State of the world's cities 2004/2005globalization and urban culture. Earthscan, London

23. Schnohr P, Gronbaek M, Petersen L, Hein HO, Sorensen TI (2005) Physical activity in leisure-time and risk of cancer: 14-year followup of 28,000 Danish men and women. Scand J Public Health 33: 244-249

24. Walk Score. Cities and neighborhoods. Available from www. walkscore.com/cities-and-neighborhoods/. Accessed 20 Nov 2014

25. Larouche R (2014) Assessing the health-related outcomes and correlates of active transportation in children and youth. Appl Physiol Nutr Metab 39:403

26. Hsu YW, Belcher BR, Ventura EE et al (2011) Physical activity, sedentary behavior, and the metabolic syndrome in minority youth. Med Sci Sports Exerc 43:2307-2313

27. Wu J, Jiang C, Houston D, Baker D, Delfino R (2011) Automated time activity classification based on global positioning system (GPS) tracking data. Environ Health: Glob Access Sci Source 10:101

28. Gorzelany J (2013) The world's most traffic-congested cities. Available from www.forbes.com/sites/jimgorzelany/2013/04/25/ the-worlds-most-traffic-congested-cities/. Accessed 20 Nov 2014

29. Thompson JL, Allen P, Cunningham-Sabo L, Yazzie DA, Curtis M, Davis SM (2002) Environmental, policy, and cultural factors related to physical activity in sedentary American Indian women. Women Health 36:59-74

30. Levine JA, Koepp GA (2011) Federal health-care reform: opportunities for obesity prevention. Obesity (Silver Spring) 19:897899

31. Hill JO, Peters JC (1998) Environmental contributions to the obesity epidemic. Science (New York, NY) 280:1371-1374

32. Levine JA, Weisell R, Chevassus S, Martinez CD, Burlingame B, Coward WA (2001) The work burden of women. Science (New York, NY) 294:812

33. Levine JA, Heet J, Burlingame B (2006) Aging on the job. Sci Aging Knowl Environ 28:pe16

34. Levine JA, Weisell R, Chevassus S, Martinez CD, Burlingame B (2002) Looking at child labor. Science (New York, NY) 296: 1025-1026

35. Farhat T, Haynie D, Summersett-Ringgold F, Brooks-Russell A, Iannotti RJ (2015) Weight perceptions, misperceptions, and dating violence victimization among U.S. adolescents. J Interpers Violence 30:1511-1532

36. Husarewycz MN, El-Gabalawy R, Logsetty S, Sareen J (2014) The association between number and type of traumatic life experiences and physical conditions in a nationally representative sample. Gen Hosp Psychiatry 36:26-32

37. Jansen PW, Verlinden M, Dommisse-van Berkel A et al (2014) Teacher and peer reports of overweight and bullying among young primary school children. Pediatrics 134:473-480

38. Giel KE, Thiel A, Teufel M, Mayer J, Zipfel S (2010) Weight bias in work settings - a qualitative review. Obes Facts 3:33-40

39. Persson G, Mahmud AJ, Hansson EE, Strandberg EL (2014) Somali women's view of physical activity - a focus group study. BMC Women's Health 14:129

40. Levine JA, Eberhardt NL, Jensen MD (1999) Role of nonexercise activity thermogenesis in resistance to fat gain in humans. Science (New York, NY) 283:212-214

41. Levine JA, McCrady SK, Lanningham-Foster LM, Kane PH, Foster RC, Manohar CU (2008) The role of free-living daily walking in human weight gain and obesity. Diabetes 57:548-554 
42. Levine JA, Schleusner SJ, Jensen MD (2000) Energy expenditure of nonexercise activity. Am J Clin Nutr 72:1451-1454

43. McCrady SK, Levine JA (2009) Sedentariness at work: how much do we really sit? Obesity (Silver Spring) 17:2103-2105

44. Levine JA, Lanningham-Foster LM, McCrady SK et al (2005) Interindividual variation in posture allocation: possible role in human obesity. Science (New York, NY) 307:584-586

45. Harris AM, Lanningham-Foster LM, McCrady SK, Levine JA (2007) Nonexercise movement in elderly compared with young people. Am J Physiol Endocrinol Metab 292:E1207-E1212

46. Levine J, Melanson EL, Westerterp KR, Hill JO (2001) Measurement of the components of nonexercise activity thermogenesis. Am J Physiol Endocrinol Metab 281:E670-E675

47. Morgan MY, Levine JA (1988) Alcohol and nutrition. Proc Nutr Soc 47:85-98

48. Thomas DM, Ciesla A, Levine JA, Stevens JG, Martin CK (2009) A mathematical model of weight change with adaptation. Math Biosci Eng 6:873-887

49. Evans BD, Rogers AE (1994) 24-hour sleep/wake patterns in healthy elderly persons. Appl Nurs Res 7:75-83

50. Shapiro CM (1982) Energy expenditure and restorative sleep. Biol Psychol 15:229-239

51. Fraser G, Trinder J, Colrain IM, Montgomery I (1989) Effect of sleep and circadian cycle on sleep period energy expenditure. J Appl Physiol 66:830-836

52. Calvin AD, Carter RE, Adachi T et al (2013) Effects of experimental sleep restriction on caloric intake and activity energy expenditure. Chest 144:79-86

53. Novak CM, Escande C, Burghardt PR et al (2010) Spontaneous activity, economy of activity, and resistance to diet-induced obesity in rats bred for high intrinsic aerobic capacity. Horm Behav 58:355-367

54. Novak CM, Kotz CM, Levine JA (2006) Central orexin sensitivity, physical activity, and obesity in diet-induced obese and dietresistant rats. Am J Physiol Endocrinol Metab 290:E396-E403

55. Kiwaki K, Kotz CM, Wang C, Lanningham-Foster L, Levine JA (2004) Orexin A (hypocretin 1) injected into hypothalamic paraventricular nucleus and spontaneous physical activity in rats. Am J Physiol Endocrinol Metab 286:E551-E559

56. Kotz CM, Teske JA, Levine JA, Wang C (2002) Feeding and activity induced by orexin $\mathrm{A}$ in the lateral hypothalamus in rats. Regul Pept 104:27-32

57. Solomon TP, Thyfault JP (2013) Type 2 diabetes sits in a chair. Diab Obes Metab 15:987-992

58. Deb S, Martin RJ (1975) Effects of exercise and of food restriction on the development of spontaneous obesity in rats. J Nutr 105: 543-549

59. Mayer EJ, Burchfiel CM, Eckel RH, Marshall JA, Haskell WL, Hamman RF (1991) The role of insulin and body fat in associations of physical activity with lipids and lipoproteins in a biethnic population. The San Luis Valley diabetes study. Arterioscler Thromb 11:973-984

60. Short KR, Vittone JL, Bigelow ML et al (2003) Impact of aerobic exercise training on age-related changes in insulin sensitivity and muscle oxidative capacity. Diabetes 52:1888-1896

61. Ravussin E, Bogardus C (1992) A brief overview of human energy metabolism and its relationship to essential obesity. Am J Clin Nutr 55:242S-245S

62. Jensen MD, Sarr MG, Dumesic DA, Southorn PA, Levine JA (2003) Regional uptake of meal fatty acids in humans. Am J Physiol Endocrinol Metab 285:E1282-E1288

63. Klein WM, Bloch M, Hesse BW et al (2014) Behavioral research in cancer prevention and control: a look to the future. Am J Prev Med 46:303-311
64. Milton K, Macniven R, Bauman A (2014) Review of the epidemiological evidence for physical activity and health from low- and middle-income countries. Glob Public Health 9:369-381

65. Biswas A, Oh PI, Faulkner GE et al (2015) Sedentary time and its association with risk for disease incidence, mortality, and hospitalization in adults: a systematic review and metaanalysis. Ann Intern Med 162:123-132

66. Lynch BM (2010) Sedentary behavior and cancer: a systematic review of the literature and proposed biological mechanisms. Cancer Epidemiol Biomarkers Prev 19:2691-2709

67. Wiktor-Jedrzejczak W, Gordon S (1996) Cytokine regulation of the macrophage $(\mathrm{M} \phi)$ system studied using the colony stimulating factor-1-deficient op/op mouse. Physiol Rev 76:927-947

68. Stanley ER, Berg KL, Einstein DB et al (1997) Biology and action of colony-stimulating factor-1. Mol Reprod Dev 46:4-10

69. Kolbe-Alexander TL, Charlton KE, Lambert EV (2004) Lifetime physical activity and determinants of estimated bone mineral density using calcaneal ultrasound in older South African adults. J Nutr Health Aging 8:521-530

70. DiPietro L (2001) Physical activity in aging: changes in patterns and their relationship to health and function. J Gerontol A Biol Sci Med Sci 56(Spec No 2):13-22

71. Beach TA, Parkinson RJ, Stothart JP, Callaghan JP (2005) Effects of prolonged sitting on the passive flexion stiffness of the in vivo lumbar spine. Spine J 5:145-154

72. Callaghan JP, McGill SM (2001) Low back joint loading and kinematics during standing and unsupported sitting. Ergonomics 44:280-294

73. Frymoyer JW (1992) Predicting disability from low back pain. Clinical orthopaedics and related research: 101-109

74. Morl F, Bradl I (2013) Lumbar posture and muscular activity while sitting during office work. J Electromyogr Kinesiol 23: 362-368

75. Jordan JL, Holden MA, Mason EE, Foster NE (2010) Interventions to improve adherence to exercise for chronic musculoskeletal pain in adults. Cochrane Database Syst Rev, Issue 1, Art. no.: CD005956

76. Zejda JE, Bugajska J, Kowalska M et al (2009) Upper extremities, neck and back symptoms in office employees working at computer stations. Med Pr 60:359-367 [article in Polish]

77. Goldberg E, Bougakov D (2005) Neuropsychologic assessment of frontal lobe dysfunction. Psychiatr Clin North Am 28(567-580): 578-579

78. Dehaene S, Changeux JP (2000) Reward-dependent learning in neuronal networks for planning and decision making. Prog Brain Res 126:217-229

79. Kreier F, Kap YS, Mettenleiter TC et al (2006) Tracing from fat tissue, liver, and pancreas: a neuroanatomical framework for the role of the brain in type 2 diabetes. Endocrinology 147:1140-1147

80. Novak CM, Zhang M, Levine JA (2006) Neuromedin U in the paraventricular and arcuate hypothalamic nuclei increases nonexercise activity thermogenesis. J Neuroendocrinol 18:594-601

81. Jean A (2001) Brain stem control of swallowing: neuronal network and cellular mechanisms. Physiol Rev 81:929-969

82. Falgairolle M, Ceccato JC, Seze M, Herbin M, Cazalets JR (2013) Metachronal propagation of motor activity. Front Biosci (Landmark Ed) 18:820-837

83. Pisotta I, Molinari M (2014) Cerebellar contribution to feedforward control of locomotion. Front Hum Neurosci 8:475

84. Luque NR, Garrido JA, Carrillo RR, D'Angelo E, Ros E (2014) Fast convergence of learning requires plasticity between inferior olive and deep cerebellar nuclei in a manipulation task: a closedloop robotic simulation. Front Comput Neurosci 8:97

85. Deliagina TG, Beloozerova IN, Orlovsky GN, Zelenin PV (2014) Contribution of supraspinal systems to generation of automatic postural responses. Front Integr Neurosci 8:76 
86. Critchley CR, Hardie EA, Moore SM (2012) Examining the psychological pathways to behavior change in a group-based lifestyle program to prevent type 2 diabetes. Diabetes Care 35:699-705

87. Sund AM, Larsson B, Wichstrom L (2011) Role of physical and sedentary activities in the development of depressive symptoms in early adolescence. Soc Psychiatry Psychiatr Epidemiol 46:431441

88. Bouchard C, Tremblay A (1990) Genetic effects in human energy expenditure components. Int J Obes 14(Suppl 1):49-55, discussion $55-48$

89. Blum K, Oscar-Berman M, Bowirrat A et al (2012) Neuropsychiatric genetics of happiness, friendships, and politics: hypothesizing homophily ("birds of a feather flock together") as a function of reward gene polymorphisms. J Genet Syndr Gene Ther 3:1000112

90. Thyfault JP, Du M, Kraus WE, Levine JA, Booth FW (2014) Physiology of sedentary behavior and its relationship to health outcomes. Med Sci Sports Exerc. doi:10.1249/MSS. 0000000000000518

91. Mellecker RR, Lanningham-Foster L, Levine JA, McManus AM (2010) Energy intake during activity enhanced video game play. Appetite 55:343-347

92. Schutz Y (1997) On problems of calculating energy expenditure and substrate utilization from respiratory exchange data. Z Ernahrungswiss 36:255-262

93. Keys A, Brozek J, Henschel A, Mickelson O, Taylor HL (1950) The biology of human starvation. University of Minnesota Press, Minneapolis

94. Keys A, Anderson JT, Brozek J (1955) Weight gain from simple overeating. I. Character of the tissue gained. Metabolism 4:427432

95. Sims EA, Horton ES (1968) Endocrine and metabolic adaptation to obesity and starvation. Am J Clin Nutr 21:1455-1470

96. Scrimshaw NS (1987) The phenomenon of famine. Annu Rev Nutr $7: 1-21$

97. Novak CM, Jiang X, Wang C, Teske JA, Kotz CM, Levine JA (2005) Caloric restriction and physical activity in zebrafish (Danio rerio). Neurosci Lett 383:99-104

98. Kotz C, Nixon J, Butterick T, Perez-Leighton C, Teske J, Billington C (2012) Brain orexin promotes obesity resistance. Ann N Y Acad Sci 1264:72-86

99. Teske JA, Levine AS, Kuskowski M, Levine JA, Kotz CM (2006) Elevated hypothalamic orexin signaling, sensitivity to orexin A and spontaneous physical activity in obesity resistant rats. Am J Physiol Regul Integr Comp Physiol 291:R889-R899

100. Trayhurn P, Bing C (2006) Appetite and energy balance signals from adipocytes. Philos Trans R Soc Lond B Biol Sci 361:12371249

101. Trayhurn P, Bing C, Wood IS (2006) Adipose tissue and adipokines - energy regulation from the human perspective. J Nutr 136:1935S-1939S

102. Toth MJ, Gottlieb SS, Goran MI, Fisher ML, Poehlman ET (1997) Daily energy expenditure in free-living heart failure patients. Am J Physiol 272:E469-E475

103. Lanningham-Foster L, Foster RC, McCrady SK et al (2008) Changing the school environment to increase physical activity in children. Obesity (Silver Spring) 16:1849-1853

104. Mellecker RR, McManus AM, Lanningham-Foster LM, Levine JA (2009) The feasibility of ambulatory screen time in children. Int J Pediatr Obes 4:106-111

105. Starling RD, Toth MJ, Carpenter WH, Matthews DE, Poehlman ET (1998) Energy requirements and physical activity in free-living older women and men: a doubly labeled water study. J Appl Physiol 85:1063-1069
106. Reynolds RF, Bronstein AM (2003) The broken escalator phenomenon. Aftereffect of walking onto a moving platform. Exp Brain Res 151:301-308

107. Koepp GA, Manohar CU, McCrady-Spitzer SK et al (2013) Treadmill desks: a 1-year prospective trial. Obesity 2013:705-711

108. Koepp GA, Manohar CU, McCrady-Spitzer SK, Levine JA (2011) Scalable office-based health care. Health Serv Manage Res 24:69 74

109. Ravussin E (2005) A NEAT way to control weight? Science 307:530-531

110. Manohar C, Levine JA, Nandy DK et al (2012) The effect of walking on postprandial glycemic excursion in patients with type 1 diabetes and healthy people. Diabetes Care 35:2493-2499

111. Dunstan DW, Kingwell BA, Larsen R et al (2012) Breaking up prolonged sitting reduces postprandial glucose and insulin responses. Diabetes Care 35:976-983

112. Hamilton MT, Healy GN, Dunstan DW, Zderic TW, Owen N (2008) Too little exercise and too much sitting: inactivity physiology and the need for new recommendations on sedentary behavior. Curr Cardiovasc Risk Rep 2:292-298

113. Basu R, Basu A, Johnson CM, Schwenk WF, Rizza RA (2004) Insulin dose-response curves for stimulation of splanchnic glucose uptake and suppression of endogenous glucose production differ in nondiabetic humans and are abnormal in people with type 2 diabetes. Diabetes 53:2042-2050

114. Fysekidis M, Cosson E, Banu I, Duteil R, Cyrille C, Valensi P (2014) Increased glycemic variability and decrease of the postprandial glucose contribution to $\mathrm{HbA}_{1 \mathrm{c}}$ in obese subjects across the glycemic continuum from normal glycemia to first time diagnosed diabetes. Metabolism 63:1553-1561

115. Ruifrok AE, Althuizen E, Oostdam N, van Mechelen W, Mol BW (2014) The relationship of objectively measured physical activity and sedentary behaviour with gestational weight gain and birth weight. J Pregnancy 2014:567379

116. Knowler WC, Barrett-Connor E, Fowler SE et al (2002) Reduction in the incidence of type 2 diabetes with lifestyle intervention or metformin. N Engl J Med 346:393-403

117. Guimaraes FC, Amorim PR, Dos Reis FF et al (2014) Physical activity and better medication compliance improve mini-mental state examination scores in the elderly. Dement Geriatr Cogn Disord 39: 25-31

118. Sardinha LB, Santos DA, Silva AM, Baptista F, Owen N (2015) Breaking-up sedentary time is associated with physical function in older adults. J Gerontol A: Biol Med Sci 70:119-124

119. Vaz Fragoso CA, Miller ME, Fielding RA et al (2014) Sleep-wake disturbances in sedentary community-dwelling elderly adults with functional limitations. J Am Geriatr Soc 62:1064-1072

120. Pahor M, Guralnik JM, Ambrosius WT et al (2014) Effect of structured physical activity on prevention of major mobility disability in older adults: the LIFE study randomized clinical trial. JAMA 311:2387-2396

121. Bennett EM (1991) Weight-loss practices of overweight adults. Am J Clin Nutr 53:1519S-1521S

122. Sarlio-Lahteenkorva S, Rissanen A (1998) Weight loss maintenance: determinants of long-term success. Eat Weight Disord 3: 131-135

123. Vuori IM (2001) Health benefits of physical activity with special reference to interaction with diet. Public Health Nutr 4:517-528

124. Kenny AM, McGee D, Joseph C, Covault J, Abreu C, Raisz LG (2005) Lack of association between androgen receptor polymorphisms and bone mineral density or physical function in older men. Endocr Res 31:285-293

125. Nguyen TV, Sambrook PN, Eisman JA (1998) Bone loss, physical activity, and weight change in elderly women: the Dubbo Osteoporosis Epidemiology Study. J Bone Miner Res 13:1458-1467 
126. Fenton M (2005) Battling America's epidemic of physical inactivity: building more walkable, livable communities. J Nutr Educ Behav 37(Suppl 2):S115-S120

127. Patel AV, Rodriguez C, Jacobs EJ, Solomon L, Thun MJ, Calle EE (2005) Recreational physical activity and risk of prostate cancer in a large cohort of U.S. men. Cancer Epidemiol Biomarkers Prev $14: 275-279$

128. Dunstan DW, Thorp AA, Healy GN (2011) Prolonged sitting: is it a distinct coronary heart disease risk factor? Curr Opin Cardiol 5: 412-419

129. Leoni LA, Fukushima AR, Rocha LY, Maifrino LB, Rodrigues B (2014) Physical activity on endothelial and erectile dysfunction: a literature review. Aging Male 17:125-130

130. Wadden TA, Steen SN, Wingate BJ, Foster GD (1996) Psychosocial consequences of weight reduction: how much weight loss is enough? Am J Clin Nutr 63:461S-465S

131. Proper KI, Heymans MW, Paw MJ et al (2006) Promoting physical activity with people in different places - a Dutch perspective. J Sci Med Sport 9:371-377
132. Unterwald EM, Ho A, Rubenfeld JM, Kreek MJ (1994) Time course of the development of behavioral sensitization and dopamine receptor up-regulation during binge cocaine administration. J Pharmacol Exp Ther 270:1387-1396

133. Greenberg JL, Lewis SE, Dodd DK (1999) Overlapping addictions and self-esteem among college men and women. Addict Behav 24:565-571

134. Ussher M, Cropley M, Playle S, Mohidin R, West R (2009) Effect of isometric exercise and body scanning on cigarette cravings and withdrawal symptoms. Addiction 104:1251-1257

135. De Maeyer J, Vanderplasschen W, Lammertyn J, van Nieuwenhuizen C, Sabbe B, Broekaert E (2011) Current quality of life and its determinants among opiate-dependent individuals five years after starting methadone treatment. Qual Life Res 20:139-150

136. Temple NJ, Burkitt DP (1993) Towards a new system of health: the challenge of Western disease. J Community Health 18:37-47

137. Popkin BM, Kim S, Rusev ER, Du S, Zizza C (2006) Measuring the full economic costs of diet, physical activity and obesityrelated chronic diseases. Obes Rev 7:271-293 